\title{
What Services Do Family Physicians Provide in a Time of Primary Care Transition?
}

\author{
Andrew W. Bazemore, MD, MPH, Stephen Petterson, PhD, Nicole Johnson, MD, \\ Imam M. Xierali, PhD, Robert L. Phillips, MD, MSPH, Jason Rinaldo, PhD, \\ James C. Puffer, MD, and Larry A. Green, MD
}

The Future of Family Medicine Report envisioned a new model of practice "committed to providing the full basket of clinical services offered by Family Medicine." In actuality, variation in that basket is considerable and may influence patients' access to care as much as supply and distribution of physicians does in the wake of health care reform.

The Institute of Medicine defines primary care as "...the provision of integrated, accessible health care services by clinicians who are accountable for addressing a large majority of personal health care needs." ${ }^{2}$ The actual scope of a primary care provider, however, varies widely and has changed over time. Trained with perhaps the widest scope among primary care providers, family physicians' scope of practice is thought to be changing as well. ${ }^{3,4}$

When applying for Part III of Maintenance of Certification (cognitive examination), all family physicians must identify areas of practice on a mandatory $(100 \%$ response rate) questionnaire included in the online application. We analyzed 3 years of responses (2006-2008) to assess what percentage of family physicians reported any service delivery across service type, all of which fall within

Submitted 31 December 2010; revised 29 March 2011; accepted 6 April 2011.

From the Robert Graham Center for Policy studies (AWB, SP, NJ, IMX, RLP); the American Board of Family Medicine (JR, JCP); and the Department of Family Medicine, University of Colorado-Denver (LG).

Funding: Funding was provided by the American Board of Family Medicine, which contracts annually for health policy/health services research conducted by the Robert Graham Center for Policy Studies related Maintenance of Certification and Quality.

Conflict of interest: none declared.

Corresponding author: Andrew Bazemore MD MPH, 1350 Connecticut Avenue, Suite \#201, Washington, DC 20036 (E-mail: policy@aafp.org).

\section{See Related Article on Page 633.}

the realm of family physician training. Specifically, we used data from a cohort applying for the Part III examination during the years 2006 to 2008 ( $\mathrm{n}=$ 26,355). Variation in services provided is considerable, and less than $40 \%$ of family physicians reported offering any services in more than half of the areas of scope considered (Figure 1).

To preserve access to services already deficient in rural and urban underserved areas, policymakers will need to consider not only workforce supply, distribution, and composition but also desirable scope of practice. Specifically, they will need to adapt policies that influence provider scope of practice to

Figure 1. Percent of family physicians offering various services.

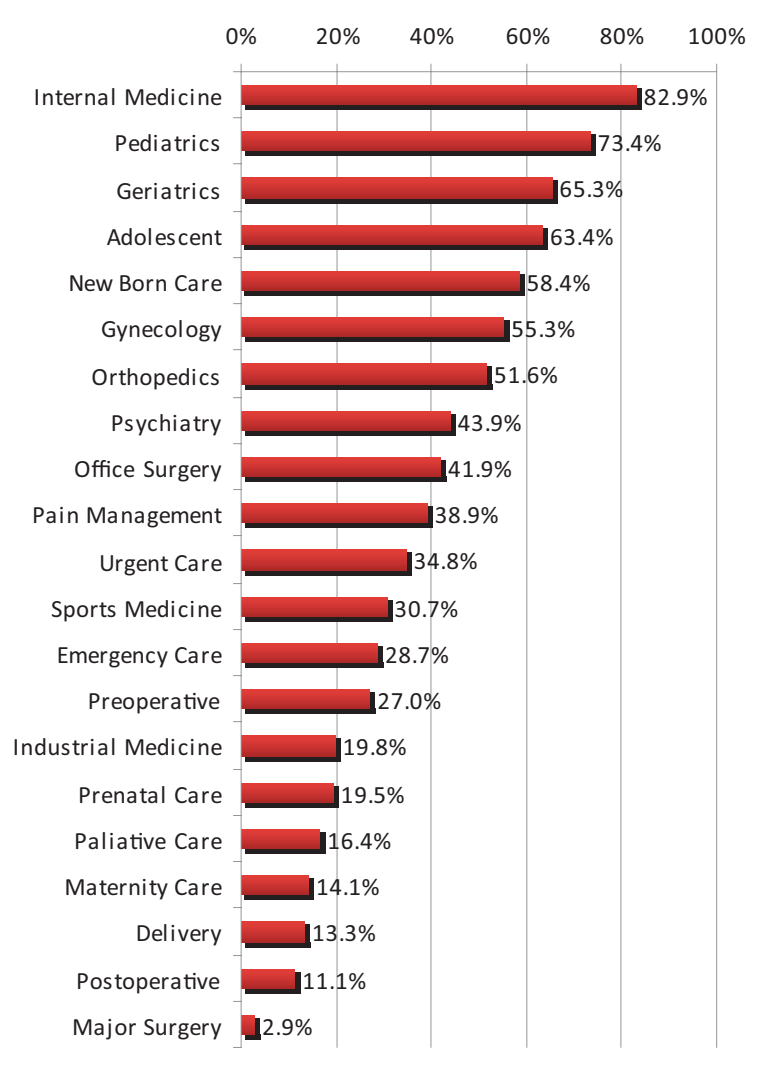


allow visions of comprehensive care within a patientcentered medical home for all Americans to be realized. These include, but are not limited to, provider payment, certification and credentialing, and undergraduate, graduate, and continuing education.

\section{References}

1. Martin JC, Avant RF, Bowman MA, et al. The Future of Family Medicine: a collaborative project of the family medicine community. Ann Fam Med 2004;2(Suppl 1):S3-32.
2. Donaldson MS, Yordy KD, Lohr KN, Vanselow NA, eds. Primary care: America's health in a new era. Washington, D.C., National Academy Press, 1996.

3. Cohen D, Coco A. Declining trends in the provision of prenatal care visits by family physicians. Ann Fam Med 2009;7(2):128-33.

4. Green LA, Dodoo MS, Ruddy G, et al. The physician workforce in the United States: a family medicine perspective. 2004. Available at: www.grahamcenter.org/PreBuilt/physician_workforce.pdf. Accessed 25 September 2011. 